\title{
Alien

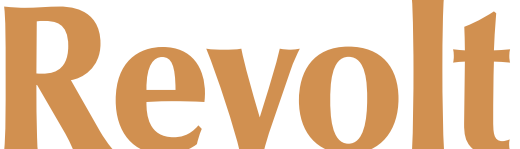 \\ (2005-2007): \\ A Case Study of the \\ First Location-Based \\ Mobile Game in Brazil
}

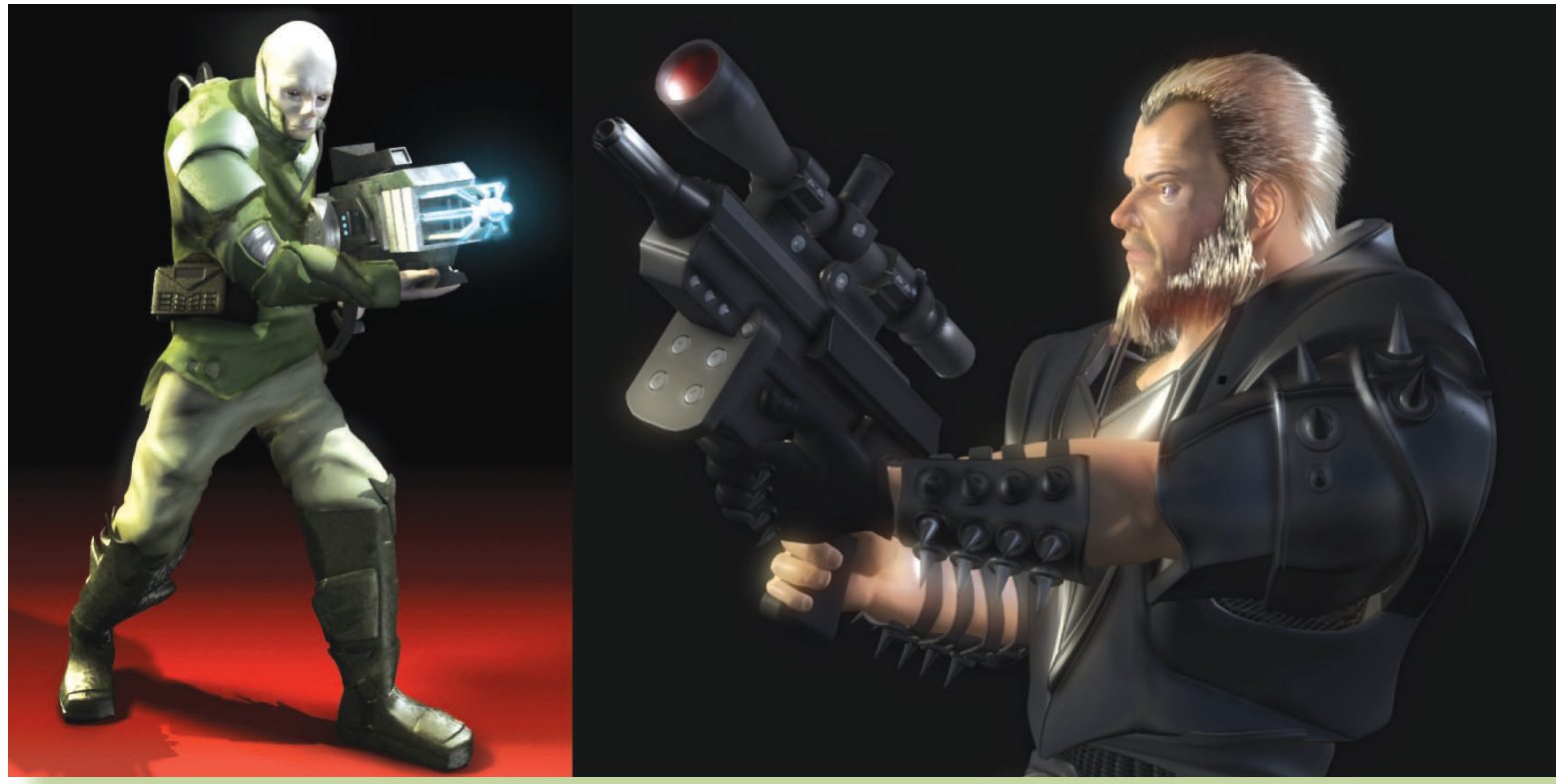

FROM “ALIEN REVOLT." LEFT: ALIEN HACKER. RIGHT: HUMAN WARRIOR.OM1ND CORP. USED WITH PERMISSION.

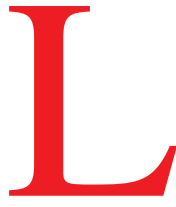

ocation-aware technology and Internet connectivity embedded in mobile phones allow users to navigate physical spaces and be connected to other users, bringing many activities formerly performed "online" to physical hybrid spaces. Among such activities are location-based

$\overline{\text { Digital Object Identifier 10.1109/MTS.2008.918036 }}$ mobile games (LBMGs), which use urban spaces as the game scenario. This article is a case study of Alien Revolt (2005-2007), the first Brazilian LBMG, released in 2005 by the company MInd Corporation and the operator $\mathrm{O} i$ in Rio de Janeiro. The game uses Java-enabled cell phones equipped with location awareness to transform the city into a battlefield. Following much of the Swedish game Botfighters'
(2001-2005) idea, the first LBMG, Alien Revolt's goal involves virtually shooting other players within a specific radius in the city space. Alien Revolt exemplifies how cell phones strengthen users' connections to physical space, because they are used as collective communication devices, rather than personal private technologies. Moreover, when used for location-based activities, the cell phone plays the 
role of a location aware technology, rather than a mobile telephone used for two-way voice communication.

LBMGs already developed in Sweden (Botfighters) and Japan (Mogi Mogi) exemplify how an "imaginary" layer on top of physical space might change the ways of interacting with the city, as well as with other users [1]. However, despite their availability, features like GPRS $^{1}$ Internet connection and location awareness are expensive for the major part of the Brazilian population. Even in large metropolises such as Rio de Janeiro, the number of subscribers who can afford playing such a game is still very restricted. Consequently, the reduced number of players in a multiplayer game occupying a geographical area that encompasses six million people ${ }^{2}$ becomes a problem, since there are large uninhabited game areas. How does Alien Revolt change the concept of what a mobile game is? What does it mean to release a location-based mobile game in a country where most of the population still uses mobile phones as mere voice communication devices? How do location-based services (LBS) redefine our ways of using the cell phone and of communicating with other users? How might the development of fourth generation $(4 \mathrm{G})$ networks

\footnotetext{
${ }^{1}$ General Packet Radio Service (GPRS) is a "system that can be implemented as a layer over Global System for Mobile Communication (GSM) systems. GPRS allows data services without the need of establishing a connection. It is considered an intermediary step $(2.5 \mathrm{G})$ to the third generation of cellular systems (3G)." See: http://www. teleco.com.br/glossario.asp?termo $=$ gprs \& Submi $\mathrm{t}=\mathrm{OK}$. Different from earlier GSM $(2 \mathrm{G})$ connections, in which the user had to pay for the connection time (circuit switched), on GPRS phones users pay for the amount of data they download to their cell phones (packet switched).
}

\footnotetext{
${ }^{2}$ The population of the entire metropolitan area of Rio de Janeiro is around 12 million. Six million corresponds to the population inside the city limits according to the Brazilian Institute of Geography and Statistics (IBGE), 2005. See: http:// www.ibge.gov.br/home/estatistica/populacao/estimativa2005/estimativa.shtm?c=1.
}

\section{The main problem in Brazil is not a lack of availability of high-end services, but their price and accessibility.}

contribute to the popularization of location-based services and social mobile networks in places such as Brazil, where the service is considered expensive, and therefore unavailable for a great part of the population?

We focus on three key issues to answer these questions. First, we explore how LBMGs change the concept of what a mobile game is, relocating the game space from the traditional tiny screen to include the urban space around it. This part contextualizes Alien Revolt among existing LBMGs, focusing on two main issues: 1) game design and narrative, and 2) game community and collaboration. Secondly, this article contextualizes Alien Revolt within the Brazilian reality of mobile technologies usage. We explore some problems faced by the game developers due to the price and availability of mobile services and handset devices in Brazil. What is found is that many of the issues delaying the popularity of the game are in fact related to the broader socioeconomic reality of the country. Lastly, this article envisions how $4 \mathrm{G}$ networks, instead of $2.5 \mathrm{G}^{3}$ and $3 \mathrm{G}^{4}$ technologies, might be

${ }^{3} 2.5 \mathrm{G}$ wireless networks use a GPRS Internet connection that runs on top of second generation (2G) digital wireless networks, also Global System for Mobile Communication (GSM).

${ }^{4} 3 \mathrm{G}$ also stands for UMTS (Universal Mobile Telecommunication System). "UMTS allows many more applications to be introduced to a worldwide base of users and provides a vital link between today's multiple GSM systems and IMT2000. The new network also addresses the growing demand of mobile and Internet applications. UMTS increases transmission speed to $2 \mathrm{Mbps}$ per mobile user and establishes a global roaming standard". Available from the International Engineering Consortium: http://www.iec.org/online/ tutorials/umts/topic01.html. a real solution for the development of location-based services and Internet access leading to the development of mobile communities in developing countries such as Brazil.

This essay contributes to the ongoing explorations of the evolution of location-based mobile applications by examining three significant arenas: 1) the emergence of the first location-based game (and the first location-based application) in Brazil, 2) the contextualization of a LBMG in a developing country, in which cell phones are still mostly thought as mobile telephones, and 3) the possibilities that the development of $4 \mathrm{G}$ networks might bring to the implementation of LBS and the creation of social mobile networks in developing countries.

The empirical work draws on a series of in-depth interviews with two game developers, who have been working on the game concept for the past three years, and two beta test players, who had played actively for over a year and a half, plus the analysis of the game website and discussion list.

\section{Alien Revolt: Changing the Concept of a Mobile Game}

\section{Game Design and Narrative}

Alien Revolt is the first locationbased mobile game commercially launched in Rio de Janeiro, Brazil. Released in May 2005, the game was the result of a combined effort among the company Mlnd Corporation, which gathered the development team together, the Brazilian operator $O i$, who provided the cell phone service, the engineers of the German company Siemens in Brazil, who developed the algorithms 


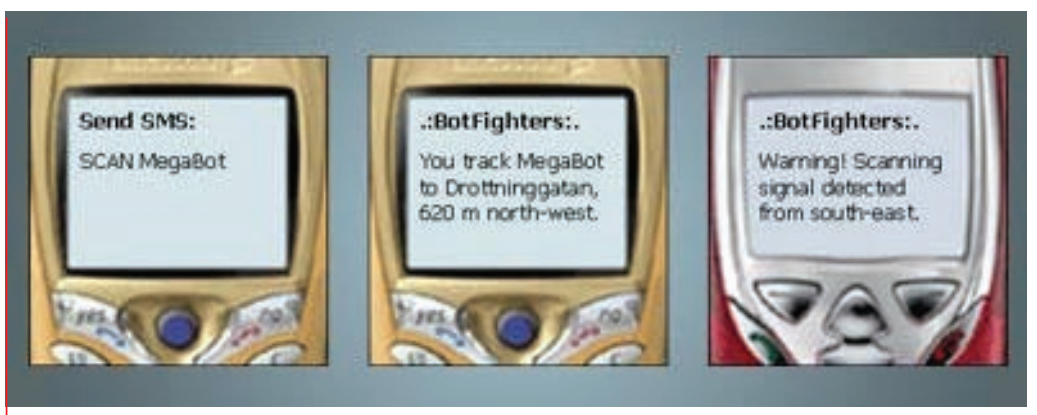

Fig. 1. Botfighters - SMS version (2001-2004). (C) It's Alive!

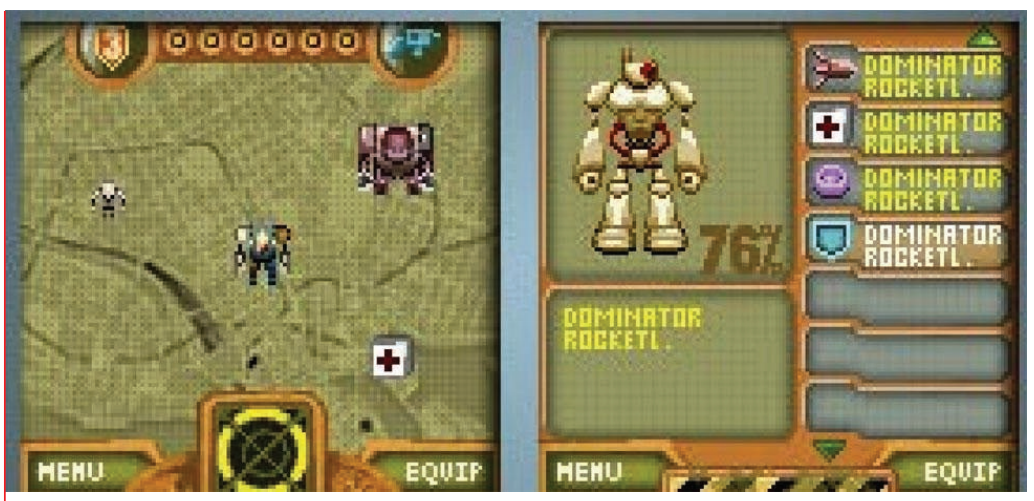

Fig. 2. Botfighters - Java version (2005). (C) It's Alive!

for the first mobile-location-aware platform in the country, and Nokia, which opened the application programming interface (API) for its Series 60 mobile phones for the game's development.

Around 2002, the game developers started thinking about creating a game that would challenge the traditional concept of mobile games, generally single-player games played on the cell phone screen. Mobile games can sometimes include multiple players via Bluetooth connectivity, which allows players to connect to one another within a 1-100 meters range. However, using Internet GPRS connection and location aware mobile phones, Alien Revolt's players can connect to any other player within a three-kilometer range.

Alien Revolt belongs to an ongoing trend in mobile gaming that seeks to expand the gameplay beyond the screen, bringing the game out of the traditional computer monitor into the city space. In 2001, Botfighters adapted the first person shooter video game design, such as Wolfenstein $3 D$ and Doom, to urban spaces. In its first version, the game used simple technology: short message service (SMS), and location aware $2 \mathrm{G}$ cell phones. The game website was used for creating the player's robot and to arm it with guns and shields. This avatar ${ }^{5}$ was then downloaded to the player's cell phone. While moving through the streets, if another player was nearby, the player received SMS messages such as "[bot nickname] within $[\mathrm{x}]$ meters." If the other robot were within 200 meters, there was a chance that the player could hit it (with basic weaponry). Each type of weapon allowed a different range of attack. Sending the produced a reply that told whether or not the shot was successful. Often the user who shot could get shots back from the attacked robot. The one who had the better

${ }^{5} \mathrm{An}$ avatar is the representation of a user's body in digital space. "shot [bot nickname]" command equipment (weapons and shields) eventually won, unless the weaker robot ran away. A successful shot could cause the death or injury of the opposed robot. The winner got credits in the form of "robucks" with which she could buy armor, radar, and weapons for her "bot" in the game website, making it more powerful. Players could also send a "search [bot nickname]" message that informed her of the distance and direction in relation to the other "bot." Tom Söderlund, one of It's Alive's co-founders, explains that shots are more accurate at a close range, "so when two players come within a half kilometer of each other, a chase often ensues" [2].

In 2004 a new version of Botfighters was released by the company Daydream to java cell phones. In this new version, besides being able to actually see the opponents on the cell phone screen radar, players could engage in specific missions posted by the developers on the game website. (See Figs. 1 and 2.)

After learning about Botfighters, Alien Revolt's developers decided to go beyond the idea of the first person shooter and develop a complete role-playing game. Moreover, instead of starting with the basic SMS technology, MInd Corporation developed the first version of the game for the expensive ${ }^{6}$ Nokia S60 java mobile phones, which allow players to create their characters on the cell phones, instead of having to go to the game website. Everything is done using the mobile platform.

Currently, it is possible to observe two trends in location-based mobile games. One, following Botfighters and Alien Revolt, tends to eliminate the desktop computer from the game interface, transforming the mobile phone into the only necessary tool for playing the

${ }^{6}$ Nokia series 60 phones cost in Brazil from 1399 to 2199 reais, the Brazilian currency (between 642 and 1000 USD). 
game. The game, therefore, takes place in two differentiated spaces: the cell phone screen and the city space. The second trend involves games such as the Japanese Mogi Mogi (2003-2007) and Blast Theory's performances like Uncle Roy All Around You (2003) and Can You See Me Now? (2001-2007) which, besides using the city space as the game scenario and employing mobile technologies, also include a fixed web component. In Can You See Me Now?, for example, the street players' mission is to chase online players. Street players run on the streets equipped with a Global Positioning System (GPS) device, a walkie-talkie, and a handheld computer, which shows a $2 \mathrm{D}$ map of the city, and the position of online players. Online players are at remote computer terminals and can "walk" through a 3D representation of the same city, in which they can see their own avatar, as well as the position/avatar of the street players. Both types of players, although occupying differentiated spaces (physical city space and digital 3D modeled city), can meet in the same hybrid space created by the game, which includes both physical and digital spaces. The game happens simultaneously in both spaces [3].

To start playing Alien Revolt, the user connects to the GPRS network with the cell phone, downloads the game and logs in with a username and a password. Alien Revolt tells the story of a group of alien creatures who try to take over the Earth. Players can decide to join the human forces or the alien army, and choose between three classes of characters: Magus, Hacker, or Warrior, each of which has different attributes and abilities.

Players up to three kilometers apart can see each other on their cell phone screen radar. The closer the opponent, the larger the character appears on the screen. Like in Botfighters, shots are more accurate at a close range. Players can

\section{In countries like Brazil, price policies speak louder than technological issues.}

then invite each other for a duel by aiming at the target and pressing "5" to attack. Attacks to the limbs and body produce less damage than a headshot. A successful attack also depends on the types of weapons, armors, and magic potions one has. If targeted, a player has the option to use a blackout mode in order to become invisible in the enemy's radar, which gives her three seconds to shoot back while hidden.

Once a player kills an enemy, the character has 10 seconds to steal her belongings, such as weapons and armors. However, if the player's backpack is full, she will not have space to carry anything and will need to give up on the equipment. The player gains experience points for each combat she wins. The amount of points given depends on the distance and level of the killed enemy, and they help the player to upgrade to the next level of the game. For each new level achieved, the player receives five points to be distributed among her character's basic attributes: strength, dexterity, vitality, and magic.

To avoid having characters occupying a higher skill level inevitably kill inexperienced characters, the experienced player is only allowed to challenge another character no more than five levels apart. For example, a player in level 16 can only battle with players in levels 11 and up. Nevertheless, lower level characters might challenge any character in the game, if they want to take the risk.

Finally, if there is no other real player around, it is possible to fight against Non-Playable Characters (NPCs), which are virtual creatures displayed in the radar by the server. NPCs have a real position in physical space and every time a player $\operatorname{logs}$ in, she is able to see four of them. If another player is around, she is able to see the same NPCs. These virtual creatures, besides being a good source of weapons and armors once killed, also fill in empty players' areas in the game. (See Figs. 3, 4, and 5.)

Alien Revolt's virtual creatures resemble those of Mogi Mogi. However, Mogi's creatures inhabit specific locations in the city space and sometimes just show up at certain times of the day. Moreover, unlike Alien Revolt, Mogi's players do not fight against each other - they trade found virtual objects and creatures in order to complete their collection. Collaboration among players is also a main theme in the hybrid reality game Uncle Roy All Around You. In this game, online players might collaborate with street players in order to help them find Uncle Roy's office [4]. Online players

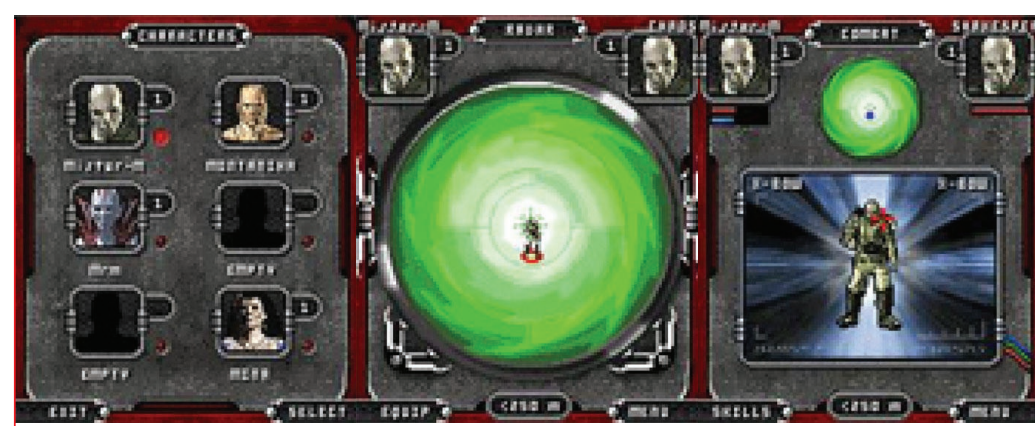

Figs. 3, 4, and 5. Character selection screen, game radar and combat mode. (c) M1nd Corporation. 
inhabit a 3D map of the city where they can see the positions of street players. On the other hand, street players walk around the city and are able to see the online players' avatars on maps representing the city on their Personal Digital Assistants (PDAs). By inhabiting a digital environment, online players have access to postcards of the city containing specific information that might help street players. Online players, however, cannot walk on the city and physically find Uncle Roy's office. Therefore, to accomplish the game's mission, both kinds of players should work together by sharing information that is space specific [5].

\section{Collaboration and Community}

One of the main goals of LBMGs is the creation of social mobile networks and communities. Although Alien Revolt is based on competition among players, collaboration is also an important factor of the game dynamics. As generally happens with massively multiplayer online role-playing game (MMORPGs), there are two main factions fighting against each other, but players inside these factions can (and should) act together in order to win the battles.

From this point of view, Alien Revolt, being a MMORPG, is also a collaborative game. As there are currently very few betatesters (11), one problem faced by them is the lack of random encounters. Licoppe \& Inada [1] refer to the type of encounter in which two players see each other on the screen without necessarily seeing each other physically as "on-screen encounters." One beta tester tells that as they all live far away from each other, the only opportunity they have to really play against real people (instead of the virtual NPCs) occurs when they schedule group meetings or one-to-one battles. Group meetings are not a foreign practice in the world of MMORPG. Games like
Everquest and Star Wars Galaxies organize conventions and fan fests, in which players can meet face-toface. However, apart from these organized meetings, MMORPGs are generally played from home on a desktop computer. Moreover, their meetings do not belong to the category of on-screen encounter, because the players actually see each other and are not only encountering other participants on their screen, depending on their position in physical space.

Some on-screen expected encounters in Alien Revolt occur as a consequence of daily displacement routes through the city. For example, one beta tester tells that he studies in Copacabana (a neighborhood in Rio de Janeiro) and there is another beta tester who lives in Copacabana. Therefore, every day in the bus on the way to school he can see the other player on his radar. However, he does not choose to play while on the move, because moving targets change their size, and are therefore more difficult to hit. He waits until the break time at school and then both have 30 minutes to battle: one from home, and another one from school.

Although scheduled encounters go along with the mechanics of traditional MMORPGs, random encounters are what really encourage gameplay in a location-based mobile game. As these games are played on the city streets, an onscreen encounter means that the players are physically close in real space, even if often both cannot see each other. In traditional MMORPGs, conversely, proximity on the screen does not mean physical proximity. Random on-screen encounters are unexpected and exciting for players because they include what Lehtonen \& Mäenpää call "street sociability," which is "the particular public form of sociality, of being at once both interested and yet indifferent and anonymous" [6, p. 156]. While in the city, one cannot foresee whom one is going to meet or what is going to happen. "It is a question of a similar anticipatory expectation as in games of change: something might happen" [6, p. 159].

The unexpected side of street sociability was experienced by one beta-tester, who wrote on the beta email discussion list:

"On Wednesday, before the holiday, I was playing inside the bus in Gávea. ${ }^{7}$ I found another player, called Maget lvl 6. At the moment the player showed up on the radar, 8 NPCs appeared as well. ${ }^{8}$ I tried to attack the player, but the system didn't allow me. ${ }^{9}$ I was frustrated.

After about 15 seconds, however, I was in the combat screen together with Maget lvl 6, and we were fighting. I don't know exactly what happened; she must have attacked me. I killed her with three shots and I was merciful not stealing anything (there was also nothing that interested me). After the combat, everything went back to normal. I killed some more NPCs and they killed me, I lost a lot of experience points, which is nothing out of ordinary.

It was one of the most exciting game experiences I've ever had. Beautiful!" [Mage Perereca. Sep. 10, 2006].

${ }^{7}$ Gávea is a neighborhood in Rio de Janeiro.

${ }^{8}$ As formerly explained, each player triggers the appearance of 4 NPCs. However, if two players are close-by, their NPC's are added. That's why he could see 8 of them.

${ }^{9}$ The system didn't allow the beta-tester to attack the other player because he was probably more than five levels below the beta tester. 
After reading this message, the attacked player explained what happened on the email list:

\section{"I met the alien Mage Perere- ca on Wednesday. Although I am in level 6 and he is level 13 , I called him for a combat just for the sake of playing with a real player, and not with a bot. The funny thing is that he showed up on my radar unexpectedly. I was in Downtown Rio." [Maget lvl 6. Sep. 11, 2006].}

Such comments show how players get excited about interacting with other real players on their screens, instead of fighting with virtual creatures. This attitude emphasizes that location-based games are indeed about developing social relations, and not only about interacting with physical space. However, these encounters, although exciting, are still rare in Alien Revolt, because, as explained, there are few beta testers, and because the city of Rio de Janeiro is indeed very large, ${ }^{10}$ so people tend to live far away from each other. A possible solution to deal with the lack of on-screen encounters suggested by the game developers is to increase the radar area. In a future version, instead of showing a three-kilometer range, the players' radar will show the five closest players, even if they are 1000 kilometers apart. This strategy is very similar to what happens in Mogi Mogi. In order to facilitate on-screen encounters, the game developers included a feature that always shows the closest player on the cell phone radar, even if she is outside the regular radar area [1]. Increasing Alien Revolt's radar will be especially useful because the game, as of October 2006, was released by the operator Brasil Telecom in all fed-

\footnotetext{
${ }^{10}$ According to the Brazilian Institute of Geography and Statistics (IBGE) (www.ibge.gov.br) Rio de Janeiro has an area of 1182 square kilometers, which corresponds to roughly 456 square miles.
}

eration states, except in São Paulo, transforming the whole country into the game space.

Another aspect that motivates collaboration is the sense of community of a game. Very early on, Alien Revolt's players created discussion forums to connect players and share game experiences. One is the already mentioned betatesters discussion list. The game also has a community in the social network website Orkut [7], and a forum on the website, all of them created by the players. Alien Master players in Alien Revolt also have the ability to create missions, gathering players with common interests. In this aspect, Alien Revolt is different from Botfighters 2, in which the missions were placed on the game website by the game developers. Creating content for the game is a critical feature of multiplayer games. Otherwise, either the game creators are forced to apply more resources to developing the game or they need to constrain the game world to a simple linear sequence of episodes. To date, all beta testers personally know each other, but in the future, when the number of players increases, these combat missions might contribute to strengthen the game sense of community.

\section{Contextualizing Alien Revolt in Brazil}

Although Alien Revolt was carefully designed and programmed, the game developers face many issues when trying to increase the game's popularity. Such issues are strictly connected to the use of mobile technologies in Brazil, and to existing socio-economic differences in the country. Brazil is well known for being one of the countries in the world with the greatest socioeconomic diversity. ${ }^{11}$ A report from the Brazilian

\footnotetext{
${ }^{11}$ IPEA attested that according to the Gini index that includes income distribution in 130 countries, Brazil is almost last, only ahead of Sierra Leone [8, p. 60].
}

Institute of Applied Economic Research [8, p. 52] shows that $10 \%$ of the population owns $46 \%$ of the country's overall income, while $50 \%$ holds only $13.3 \%$ of this amount. Moreover, the wealthiest $1 \%$ of the population (around 1.7 million people) owns the same amount as the poorest $50 \%$ of the population (about 85 million). These economic differences influence the diverse use of communication technologies across the country, specifically of mobile telephones [9].

Three issues influence the pattern of cell phone use in Brazil. First, the large number of prepaid phones. The majority of cell phones in the country (ca. 80\%) [10] are pre-paid; that is, the user does not need to pay a monthly subscription and has the option to buy a pre-paid calling card in order to place calls. As Brazil adopts the calling party pays (CPP) policy, by which a user only pays for the calls she places, several users only use their phones to receive calls, having therefore a type of "free phone": a device that cannot place calls, but allows them to be always available to others. In the CPP mode, users can still receive calls, even if they choose not to buy a prepaid card.

This fact allows us to conclude that, although high-end services like Alien Revolt are available on pre-paid phones as well, the majority of users are not willing to pay for them, because they are mostly concerned about controlling costs. One consequence of this fact is that cell phones in Brazil, unlike countries such as Finland and Japan, in which the use of SMS and mobile Internet is high (see [11]-[16]), are still mostly used for voice communication.

The second major influence on how customers use cell phones is related to the price of the service. Although Brazil is the fifth country in the world in 
absolute number of cell phones ${ }^{12}$ [17], the number of monthly minutes spoken on the mobile (Minutes of Use, MOU) is actually very low compared to other Latin American countries. A financial report developed by América Móvil for the second quarter of 2006 [18] states that while Brazilians speak on average 66 minutes per month on a mobile phone, Chileans talk as much as 126 minutes, Argentineans, 135, Mexicans, 111, and Colombians, 107.

Two reasons are potential causes of this fact. One is related to the large number of pre-paid phones, as pre-paid phone owners tend to speak less on their cell phones than regular subscribers, since the air minute on a pre-paid phone is more expensive. Also, as mentioned earlier, often pre-paid phone owners just use their phones to receive calls. A second cause is associated with the price of the service. Countries with higher price per wireless minutes are also those with fewer monthly spoken minutes. For example, Argentina has a relatively low price per wireless minute (0.07 USD) and the country has one of the highest MOU in Latin America (135 minutes). On the other hand, the cost per minute in Brazil is three times as expensive, around 0.26 USD [19], which leads to a low MOU. The high cost is not only connected to spoken minutes. Services such as text messaging (SMS) and GPRS Internet connection also represent additional costs.

To play Alien Revolt, users are charged for 1) the SMS messages they send for each combat (around 0.07 real), 2) the chat messages they send to each other (around 0.15 real) and 3) the GPRS Internet connection from the operator (around

\footnotetext{
${ }^{12}$ As of December 2007, Brazil had roughly 12 million cell phones, behind only Russia (155 million), India (166 million), U.S.A. (237 million), and China (481 million) [19].
}

7 reais per MB). ${ }^{13}$ Because users must pay for each message they send, plus the price of the GPRS connection, some players admit they gave up playing because it was becoming too expensive. A future solution to this problem includes changing the connection technology, so that the operator charges a flat rate of 9.90 reais (4.5 USD) for unlimited Internet monthly access. According to the game developers, the operators, however, are still reluctant in adopting this flat fee, fearing to loose profits.

Finally, the price of the handsets is another major issue that influences cell phone use in Brazil. As an example, Nokia's website $[21],{ }^{14}$ the major cell phone producer in the country [21], does not offer a single device for less than $182 \mathrm{USD}^{15}{ }^{15}$ which is just about an entire month's earnings for the majority of the population [9]. The IPEA report [8] shows that more than $50 \%$ of the Brazilean population lives with less than one minimum salary ${ }^{16}$ per month (162 USD). As previously mentioned, as of August 2006 Alien Revolt only worked on the Nokia series 60 phones, which cost between 1399 and 2199 reais (642 and 1000 USD). The conclusion that necessarily comes from this fact is that the game is only available to a very small percentage of the population. In fact, fewer than three million people in

\footnotetext{
${ }^{13}$ One real converts to 0.56 USD (January 18, 2008).
}

${ }^{14}$ Like in the U.S., operators sometimes have special deals and promotions, which include a free phone together with the purchase of a specific plan.

\footnotetext{
${ }^{15}$ The minimum salary was created in Brazil in 1936 by President Getúlio Vargas. At its inception, the minimum salary was supposed to cover the basic monthly needs of a 4-person family (food and housing).
}

${ }^{16}$ According to the Brazilian Institute of Geography and Statistics (IBGE), Brazil has roughly 190 million inhabitants; http://www.ibge.gov.br/home/disseminacao/online/popclock/popclock.php. the whole country earn more than 1700 reais a month. ${ }^{17}$

The game developers invested in at least three solutions to make the game available to a larger segment of the population. The first effort, as previously mentioned, was the release of the game in other federation states, allowing high income people from other states to play as well. A second solution was the development of the game for the Nokia series 40 phones, which are substantially cheaper than the Series 60. Series 40 phones cost between 49 and 3000 reais (23 and 1380 USD), but most devices are under 200 reais $(90$ USD). The new game version for the Nokia series 40 phones was released in September 2006.

Finally, in an inverted Botfighters strategy, the developers decided to create an SMS version of the game, released in December 2006. The current Java version is complex and requires high-end cell phones able to run Java applications. The phones must have color screens and a minimum screen resolution able to display detailed graphics. The SMS version, on the other hand, works on standard cell phones, since the only technological requirement is the capacity to send text messages and the embedded location aware platform.

\section{G: A Way of Popularizing LBS in Developing Countries?}

\section{Development of Location Awareness}

Location-based services were launched in the late 1990s, but just came to the Brazilian market in 2006. The same platform used

\footnotetext{
17"ImaHima is the Japanese expression for "are you free now?" It is a mobile, location-integrated, community, and instant messaging service allowing users to share their current personal status (location, activity, mood) publicly and privately with their buddies and send picture and instant messages to them." (1999-2004, ImaHima, Inc.) http://www.imahima.com/ihcorpv3/portfolio/ imahima.html
} 
for Alien Revolt has been used in the development of other commercial applications, such as $\mathrm{O} i$ Encontra (Oi Encounter), a service that allows users to find each other. By typing a cell phone number on the mobile screen, users can see on a 2D map the location of the requested cell phone. The service, however, does not allow the tracking of ALL cell phones. In order to be tracked, each user must register and authorize being tracked by certain numbers, at specific times.

Perhaps location awareness is the most relevant feature of the cell phone in defining how mobile interfaces can influence our interaction with other users and with the space we inhabit. When a mobile interface knows where it is in physical space it automatically acquires a different meaning from a fixed telephone and from a desktop computer, since one of its key functions becomes navigation in physical space. Internet capability added to location awareness, as it happens in applications such as Alien Revolt and $O i$ Encontra, allows users to develop a unique relationship to physical space, as well as to the Internet, since digital information can be linked to physical locations. Location-based services are likely to change what is understood by a mobile phone, since users will no longer employ their phones only to talk, but also to locate things in physical space, including other people. Consequently, mobile phones start to be used as social networking devices.

Currently location-based services are being developed for applications oriented in two complementary directions: 1) linking information to places, and 2) the creation of social mobile networks and interpersonal communication.

The first trend involves what Barkhuus and Dey [22] call position-aware applications, by which the device knows where it is in public spaces and is therefore

\section{Other examples of Flash Mobs are public pillow fights, and the worship of a gigantic Tyranosaurus Rex in Toys "R" Us.}

able to receive geo-localized information. Examples of position aware applications are Siemen's Digital Graffito and GeoVector applications. Digital Graffitto is a service for the mobile phone that allows SMS messages to be sent to places, instead of people. When messages are attached to coordinates in physical space, users can receive them when entering a specific geographical area. Possible uses for this software include, for example, sending a message to an area in a shopping mall to announce to passersby who subscribed to the "shopping mode" that some stores are having sales, as well as tourism applications. The use of location-aware SMS might expand the audio-tour concept, currently restricted to closed museum spaces, to larger outdoor spaces. For instance, tourists visiting old ruins might receive site-specific historical information about monuments just by approaching them. GeoVector is a local search technology that allows users to use their mobile phones as pointing devices in physical space, in order to check and get directions to nearby restaurants and movie theaters. Location-aware services have been growing since NTT DoCoMo launched DoCo-Navi in 1999 in Japan, providing real-time maps and directions on handheld devices [23, p. 97].

The second trend includes what Licoppe and Inada call an engineering of traffic encounters, by which "the terminal projects a digital "aura" over a short distance, so that when the terminal projecting a compatible profile passes close by, information can be exchanged $[1, p$.
40]. Such applications fall within Barkhuss and Dey's [22] concept of location-tracking, since they allow other parties to be aware of somebody else's mobile technology physical position. They include interpersonal awareness devices, like the Japanese LoveGetty [24].

Also included in this category are applications that mix mobility in physical space with mobility on the mobile screen. Such applications represent an area of activity accessible on mobile screens, where the users' positions are directly related to their real position in space $[1, \mathrm{p}$. 40], as it occurs with software such as ImaHima ${ }^{18}$ in Japan, a type of location-based instant messenger (LBIM), and LBMGs, such as Mogi Mogi [1], Can You See Me Now? [3], Uncle Roy All Around You [4], Botfighters and Alien Revolt. Such games and applications allow people to find each other and to connect to each other according to their movement in physical space.

Location-based applications are becoming popular around the world, especially in Japan and Scandinavian countries, and many believe they will constitute a critical component in the future of advanced mobile services [1, p. 39], especially in the development of collaborative applications and mobile social networks. However, it is worth asking how LBS will become popular in developing countries such as Brazil, given the afore-mentioned difficulties with price of the service, handsets, and access to the mobile network.

\footnotetext{
${ }^{18}$ Other examples of Flash Mobs are public pillow fights, and the worship of a gigantic Tyranosaurus Rex in Toys " $R$ " Us. The event took place in many cities in the world, such as New York, Seattle, Madri, and Sidney
} 


\section{Envisioning 4G in Developing Countries}

Location awareness by itself is not very useful for creating social mobile networks without the proper ability to connect to the Internet and to develop peer-to-peer networks. Investments on $4 \mathrm{G}$ mobile networks in developing countries might represent a two-fold solution to the popularization of mobile social networks, such as the ones found in LBMGs, via 1) the inclusion of location awareness in a large number of mobile devices, and 2) the increasing access to Internet connection and $\mathrm{P} 2 \mathrm{P}$ networks through diverse interfaces.

As formerly stated, the main problem in Brazil is not a lack of availability of high-end services, but rather their price and accessibility. We have seen that Alien Revolt faced many issues due to the status of mobile technologies in the country, especially due to prices of the service and handsets. Likewise, services like Oi Encontra will only be largely used when devices enabled to run it become more affordable, along with the price of the Internet connection.

Short-term solutions to these problems, as proposed by Alien Revolt's developers, include 1) a lower price GPRS Internet connection, and 2) the development of simpler versions of location-based applications for low-end users. Negotiations with cell phone operators are underway in order to charge customers a flat monthly fee for Internet access. This solution would lower the price of the service and motivate common users to try location-based applications. The second solution proposed by Mlnd Corporation is the development of two versions of the same product, one targeting highend consumers and another one for simple devices. For example, MInd Corporation and $\mathrm{Oi}$ developed an application that allows customers to $\log$ in to the website of the Municipal Agency for Traffic Management in Rio de Janeiro (CET-Rio) and check out the traffic during rush hours through live videos of street cameras spread out the city. Simultaneously, they also developed a low-end version for simpler cell phones, in which instead of checking live videos, the user downloads snapshots. Similar solutions can be developed for LBS, as is the case of the SMS version of Alien Revolt and the new version for the Nokia Series 40 cell phones.

However, a long-term solution will most likely include investments in $4 \mathrm{G}$ networks. We have seen that LBS in Brazil have been developed on a $2.5 \mathrm{G}$ network over a GPRS Internet connection. Vivo, the major operator in the country, has been announcing the release of $3 \mathrm{G}$ services for more than two years as of July 2007, but the proposed high-speed network, besides only working in extremely expensive cell phones, is restricted to few areas in Rio de Janeiro and São Paulo. This difficulty in both developing the technology and popularizing the service indicates that the future of mobile social communities and locationbased applications is not tied to the development of $3 \mathrm{G}$ systems related to cellular structures.

According to Frattasi et al.,

"it was originally expected that the fourth generation (4G) would follow sequentially after $3 \mathrm{G}$ and emerge between 2010 and 2015 as an ultra-high-speed broadband wireless network" [25, p. 35].

However, this linear $4 G$ vision is being replaced by what the European Commission calls a concurrent $4 G$ vision. This type of system will "ensure seamless service provisioning across a multitude of wireless systems and provide an optimum delivery via the most appropriate (i.e., efficient) network available" [25, p. 35].

The diversity of networks and connection technologies might represent a real chance for developing countries to finally introduce popular high-end services. Among many envisioned advantages of $4 \mathrm{G}$ networks (see [25] -[27]), four might be specifically relevant for countries such as Brazil:

\section{1) Cost:}

" $4 \mathrm{G}$ systems will prove far cheaper than $3 \mathrm{G}$, since they can be built atop existing networks. (...) Also an open system IP wireless environment would probably further reduce costs for service providers by ushering in an era of real equipment interoperability" [27, pp. 2317-2318].

Currently, the cost of the service is one of the main reasons why high-end location-based applications are not popular in Brazil.

2) Network availability: $4 \mathrm{G}$ will combine existing $2 \mathrm{G}$ wireless networks, local area networks (LANs), Wi-Fi, Wi-Max, and P2P networks, like Bluetooth, taking advantage of the infrastructure that is already developed, rather than creating an entirely new standard, as is the case of 3G UMTS. The use of diverse network connections will most likely include more users in the connection network, which will not depend solely on the expensive GPRS or UMTS standards. Consequently, more users will have access to the Internet and to other users.

3) Terminal heterogeneity: According to Frattasi et al.,

"terminal heterogeneity refers to the different types of terminals in terms of display size, energy consumption, portability / weight, complexity and so forth" [25, p. 37].

4G users will be able to have devices that not only access different types of networks depending on what is available in the area, but also access these networks from different interfaces, like cell phones, smart 
phones, computers, Personal Digital Assistants (PDAs), and cars. We have seen that one of the main problems for the popularization of highend services in Brazil is the price of the cell phone. Furthermore, as is the case with Alien Revolt, only specific expensive cell phones can be used for certain high-end applications. The availability of more types of devices able to access the network increases the chances that users own at least one of these interfaces. However, as Frattasi et $a l$. point out, the mobile phone is still expected to be one of the most popular devices to access the network [25, p. 40]. Currently, the prices of handsets in Brazil are dropping and many operators, as it occurs in the United States, offer devices for free with a subscription plan. Furthermore, some initiatives are being taken to fill in this gap. For instance, Philips is negotiating with mobile phone producers for the release of a device for less than 20 dollars, directly targeting the low-income population [28].

4) Finally, location awareness can be accomplished in three different ways in $4 \mathrm{G}$ networks: IP location, outdoor location, and indoor location. According to Santhi et al.,

\begin{abstract}
"In 4G-style mobile IP, each cell phone is assigned a permanent "home" address, along with a "care-of" address that represents its actual location" [27, p. 2319].
\end{abstract}

Outdoor location awareness might be accomplished by embedding a GPS receiver in the user terminal. Additionally, indoor localization "which is important in order to provide, for instance, the guided tour in a museum, requires the cooperation of short range wireless networks" [25, p. 40], like Bluetooth, or Wi-Fi. The combination of these three types of location awareness will turn LBS in an integral part of $4 \mathrm{G}$ services and applications.

\section{While crossing the street they took out their shoes and repeatedly beat them on the ground.}

Frattasi et al. [26, pp. 60-61] point out that $4 \mathrm{G}$ services have strong social dimensions allowing enhanced services with $\mathrm{P} 2 \mathrm{P}$ networks, and cooperative services, such as group building, social networks, and cooperative resource sharing. Besides helping to popularize LMBG, the development of $4 \mathrm{G}$ might prove helpful for fostering other types of social mobile networks in developing countries. For example, the phenomenon known as Flash Mobs, in which groups of people coordinate an innocuous and pointless public demonstration via SMS, also took place in Brazil. In 2004, a group of people suddenly gathered in Avenida Paulista, one of the main avenues in São Paulo. While crossing the street, they took out their shoes and repeatedly beat them on the ground [29]. The manifestation, however, was an isolated act, with no followups. Moreover, the gathering was mostly organized via Internet, not cell phones, as it generally occurs. With 4G networks, mobile devices might start playing a more relevant role in organizing people in public spaces, as in Flash and Smart Mobs [23].

A second example where the development of $4 \mathrm{G}$ services might motivate the creation of locationaware social networks is based on the popularity of social networking websites in the country. Following the trend of online communities such as MySpace and Facebook, Orkut became the most popular social networking website in Brazil. More than half Orkut's user profiles belong to Brazilians. Although the website appeals mostly to teenagers and young adults, the phenomena in the country is not restricted to these segments of the population; and it includes people from all ages - as long as they have access to an Internet connection [30]. However, Internet connections are even scarcer than the number of cell phones in the country, a fact that will always exclude a large segment of the population from belonging to such communities. Given this scenario, we might suggest that the deployment of $4 \mathrm{G}$ technologies, with terminal heterogeneity and network availability, might contribute to transform social online networks into mobile communities, such as the afore-mentioned ImaHima. Such communities would not only help people to meet online, but also to use their cell phones to organize themselves in public spaces.

\section{Location-Based Services, 4G, and Hybrid Spaces}

LBS might be an important part of the future of mobile technologies by linking information to spaces and connecting people in physical spaces. However, when considering the development of mobile social networks in developing countries, a broader perspective should be addressed, which includes LBS in the context of $4 \mathrm{G}$ networks. This approach focuses not only on the creation of new LBS, but addresses the main issues that inhibit popularity of mobile communities in developing countries: price of the service, price of the handset, and network availability. Through the case study of the first Brazilian LBMG, Alien Revolt, we have seen that in countries like Brazil, price policies speak louder than technological issues. Nevertheless, the development of Alien Revolt 
shows that Brazil is included in a new trend of mobile technologies development, which involves geolocalized information attached to the mobile device, and the development of $3 \mathrm{G}$ networks. However, this paper proposed that a real change in the way technology is used will possibly come with the development of $4 \mathrm{G}$ networks.

By its increasing ability to connect groups of people across the networks, 4G communication technologies (including cell phones) will be regarded as more than private two-way voice communication devices. The concept of social collective interfaces will come from the users' ability to interact with each other in physical spaces. As multi-user games, LBMGs relocate previous MMORPGs to be played in urban hybrid spaces, creating a hybrid communication space that includes physical and online spaces. I refer to this new spatial perception as hybrid spaces.

\section{Author Information}

Adriana de Souza e Silva is an Assistant Professor in the Department of Communication, North Carolina State University, 201 Winston Hall, Campus Box 8104, Raleigh, NC 27695-8104. She is also director of the Mobile Gaming Reseach Lab, and a faculty member of the Science, Technology and Society Program at NCSU. Email: souzaesilva@ncsu.edu.

\section{References}

[1] C. Licoppe, and Y. Inada, "Emergent uses of a multiplayer location-aware mobile game: The interactional consequences of mediated encounters," Mobilities, vol. 1, pp. 39-61, Mar. 2006.

[2] T. Söderlund, "It's alive," Wireless Rev. Nov. 2001; http://wirelessreview.com/dataapps/wireless_tom_sderlund/.

[3] S. Benford, R. Anastasi, A. Flintham, A. Dozd, A. Crabtree, C. Greenhalgh, et al., "Coping with uncertainty in a location-based game," IEEE Pervasive Computing, vol. 2, pp. 34-41, Jul.-Sep. 2003

[4] S. Benford, M. Flintham, A. Drozd, R. Anastasi, D. Rowland, N. Tandavanitj, M.
Adams, J. Row-Farr, A. Oldroyd, and J. Sutton, "Uncle Roy all around you: Implicating the city in a location-based performance," Proc. ACM Advanced Computer Entertainment (ACE 2004). Singapore: ACM, Jul 2004; http://www.amutualfriend.co.uk/papers/3. Uncle_Roy_at_ACE.pdf.

[5] A. de Souza e Silva and G. Delacruz, "Hybrid reality games reframed: Potential uses in educational contexts," Games and Culture, vol. 1, pp. 231-251. Jul. 2006.

[6] T. K. Lehtonen, and P. Mäenpää, "Shopping in the East Centre Mall," in The Shopping Experience, P. Falk and C. Campbell, Eds. London, U.K.: Thousand Oaks, and New Delhi: Sage, 1997, pp. 136-165.

[7] Orkut, Google, 2008; http://www.orkut. com.

[8] IPEA (Brazilian Institute of Applied Economic Research), Radar Social 2005. Brasília, Brazil, 2005; http://www.ipea.gov.br/Destaques/livroradar/03.renda.pdf.

[9] A. de Souza e Silva, "Cell phones and places: The use of mobile technologies in Brazil," in Societies and Cities in the Age of Instant Access, H. Miller, Ed. New York, NY: Springer-Verlag, pp. 295-310.

[10] Teleco: Informação em Telecomunicações, "Por que se fala pouco no celular no Brasil," Seção: Comentários Teleco, Sept. 2006; http://www.teleco.com.br/comentario/ com174.asp.

[11] R. Ling, The Mobile Connection: The Cell Phone's Impact on Society. San Francisco, CA: Morgan Kaufmann, 2004.

[12] E.L. Kasesniemi, and P. Rautiainen, "Mobile culture of children and teenagers in Finland," in Perpetual Contact: Mobile Communication, Private talk, Public Performance, J. Katz and M. Aakhus, Eds., Cambridge, U.K.: Cambridge Univ. Press, 2002, pp. 170-192.

[13] R. Ling, and B. Yttri, "Hyper-coordination via mobile phones in Norway," in Perpetual Contact: Mobile Communication, Private Talk, Public Performance, J. Katz and M. Aakhus, Eds. Cambridge, U.K.: Cambridge Univ. Press, 2002, pp. 139-169.

[14] C.A. Rivière, and C. Licoppe, "From voice to text: Continuity and change in the use of mobile phones in France and in Japan," in The Inside Text: Social, Cultural and Design Perspectives on SMS, R. Harper, L. Palen, and A. Taylor, Eds. The Netherlands: Springer, 2005, pp. 103-126.

[15] M. Ito, and D. Okabe, "Intimate connections: Contextualizing Japanese youth and mobile messaging," in The Inside Text: Social, Cultural and Design Perspectives on SMS, R. Harper, L. Palen, and A. Taylor, Eds. Netherlands: Springer, 2005, pp. 127-146.

[16] T. Kopomaa, "The breakthrough of text messaging in Finland," in The Inside Text: Social, Cultural and Design Perspectives on SMS, R. Harper, L. Palen, and A. Taylor Eds. Netherlands: Springer, 2005, pp. 147-160.
[17] Teleco: Informação em Telecomunicações, "Estatísticas de celular no mundo," Seção: Telefonia celular, Sept. 2006; http:// www.teleco.com.br/pais/celular.asp.

[18] C. Garcia-Moreno and P. A. Gérard, "América Móvil's second quarter of 2006 financial and operating report," América Móvil, S.A. de C.V. ("America Móvil") [BMV: AMX] [NYSE: AMX] [NASDAQ: AMOV] [LATIBEX: XAMXL], Mexico City, Jul. 2006; http://www.americamovil.com.

[19] Teleco: Informação em Telecomunicações, "Preços e tarifas do cellular," Seção: Telefonia celular, Aug. 2006; http://www. teleco.com.br/tarifacel2.asp.

[20] Nokia-submarino; http://nokia.submarino.com.br/nokia/.

[21] Teleco: Informação em Telecomunicações, (2006c, Jan. 25). "Celular cresce 20,6 milhões e tem produção recorde em 2005," Jan. 2006; http://www.teleco.com.br/imprimir.asp?pagina $=/$ comentario/com140.asp.

[22] L. Barkhuus and A. Dey, "Locationbased services for mobile telephony: A study of users' privacy concerns," in Proc. INTERACT 2003, 9 TH IFIP TC13 Int. Conf. Human-Computer Interaction, July 2003; http://intel-research.net/Publications/Berkeley/072920031046_154.pdf.

[23] H. Rheingold, Smart mobs: The next social revolution. Cambridge, MA: Perseus, 2002.

[24] Y. Iwatani, "Love: Japanese style," Wired News, Nov. 1998; http://www.wired.com/ news/culture/0,1284,12899,00.html.

[25] S. Frattasi, S., H. Fathi, F. Fitzek, R. Prasad, and M. Katz, "Defining 4G technology from the user's perspective," IEEE Network, vol. 20, pp. 35-41, Jan.-Feb. 2006.

[26] S. Frattasi, H. Fathi, A. Gimmler, F. Fitzek, and R. Prasad, "Designing socially robust 4G wireless services," IEEE Technology \& Society Mag., vol. 25 pp. 51-64, Sum. 2006.

[27] K. Santhi, V. Srivastava, G. SenthilKumaran, and A. Butare, "Goals of true broadband's wireless next wave (4G-5G)," in Proc. IEEE 58th Vehicular Technology Conf. (VTC), vol. 4, pp. 2317-2321.

[28] O Globo. "Celulares a menos de US\$ 20?," Informática, Nov. 2005.

[29] Internet Group, "Primeiro "flash mob" do Brasil tem pés descalços e ode ao MP3," Último Segundo; http://ultimosegundo. ig.com.br/materias/mundovirtual/13025011303000/1302842/1302842_1.xml.

[30] S. Fragoso, "Eu odeio quem odeia... Consideraçoões sobre o comportamento dos usuarios brasileiros na 'tomada' do Orkut," Intercom - Sociedade Brasileira de Estudos Interdisciplinares da Comunicaçao -- XXIX Congresso Brasileiro de Ciências da Comunicaçao - UnB, Sep. 2006; http://www.baguete. com.br/img/noticias/1157576978_fragoso_intercom06.pdf. 